\title{
Money for Nothing, the Cricks for Free
}

Five Paradoxes in EU Migration Policy

Jan Claudius Völkel

\author{
CMS 2 (2): 151-180
}

DOI: $10.5117 / C M S 2014.2 . V O L K$

\begin{abstract}
The conflictive targets of achieving security for itself, and assuring basic human rights for irregular migrants, have led to paradox EU migration policies. The increasing perception of (uncontrolled) immigration as a potential security threat has contributed to a migration approach that is driven primarily by principles of defence and deterrence. Focusing on the Mediterranean region, this article points to five paradoxes, in areas where EU immigration policies and actions not only fail to reach their targets but often generate opposite outcomes. This comes at high costs in terms of financial contributions and human losses. In addition, these policies unnecessarily reduce the EU's negotiating power in other policy fields. The article concludes with recommended changes in EU migration policies and calls for an end to the hitherto security-dominated approach to migration.
\end{abstract}

Keywords: European Union, Migration Policy, Stockholm Programme, Securitization, Frontex, Readmission Agreements, North Africa, Arab Spring

\section{Introduction}

2014 is the final year of the European Union's Stockholm Programme period. Agreed upon by the European Council in December 2009, the Stockholm Programme outlined the plans for developing the EU's Justice and Home Affairs (JHA) policies for the following five years, including the main aim of making the European Union an area of freedom, security, and justice (European Council, 2010). This strategy, in its chapters 5 and 6, also tackles the question of how to deal with people who intend to enter the EU, whether voluntarily (mainly for working purposes, coming on regular or irregular 
ways) or enforced (mainly asylum seekers, but also trafficked persons). Maintaining the balance between being open for those who need access while protecting itself from uncontrolled irregular influxes of migration is the core challenge for the EU, as outlined in those two chapters.

In the action plan related to the Stockholm Programme, the European Commission (2010:7) stated in April 2010 that ' $t$ the prevention and reduction of irregular immigration in line with the Charter of Fundamental Rights is equally important for the credibility and success of EU polices [sic!]'.

The years of the Stockholm Programme 2010-2014 have seen major events with lasting impact on the EU's performance in the area of migration and asylum policy. First, the implementation of the Lisbon Treaty, enacted in December 2009, brought fundamental changes to the EU structure as a whole, including how it presents itself to, and interacts with, external actors (Lavallée, 2011). Second, the pervasive economic crisis in many EU Member States has reduced the overall disposition to welcome people from other parts of the world and triggered massive population movements from southern to northern EU Member States of +45 per cent between 2009 and 2011 (OECD, 2013: 11). Non-EU immigrants seeking employment now face increased competition from EU passport holders with unrestricted EU-wide work permissions, which now (as of January 2014) includes Bulgarians and Romanians. Third, the accession of Croatia to the EU on 1 July 2013 has further extended the external borders of the EU, now being adjacent to Bosnia-Herzegovina and - though only with a very short borderline of just $25 \mathrm{~km}$ - Montenegro. With the notable exception of Kosovo, all official passport holders from western Balkan states have since December 2010 enjoyed visa-free access to the EU for up to go days (within a period of 18 o days). Fourth, after the inception of Frontex as the European Border Protection Agency in 2004, major initiatives aimed at tightening control of the EU's external EU borders have been introduced, the digital fingerprint database EURODAC or the satellite-based surveillance programme EUROSUR representing some of the most prominent examples here.

Finally, the revolutionary events in North Africa as well as in many countries of the Middle East have changed significantly the political, societal, and economic circumstances along the eastern and southern Mediterranean coastline. Regimes that over decades had seemed stable have suddenly begun to face unprecedented protests from their own people. As recent as 2012, indices such as Freedom House or the Bertelsmann Transformation Index (BTI) recognized remarkable improvements in the state of democracy in several countries - Egypt and Tunisia in particular - 
though most improvements in Egypt have been rolled back since summer 2013 (Völkel, 2013).

These five developments truncate the EU's migration cooperation, which has traditionally viewed North African states as pre-frontier barriers to irregular entries. After analysing the altered circumstances under which EU migration policy has been formulated and implemented (after both the changes brought by the Lisbon Treaty and the changes induced by the Arab Spring), five paradoxes will be elaborated that show how intentions and outcomes in EU migration policies often differ. The guiding hypothesis states that the increasing perception of irregular migration as a threat to security (rather than a humanitarian disaster) has led to schizophrenic EU actions that exacerbate the problems they are intended to resolve. In advancing this argument, the article draws on Düvell's (2011:275) idea that 'regulations that are meant to prevent unwanted migration often have unintended side-effects and instead encourage irregular migration'. In addition, this article argues that such regulations are hardly cost-effective and instead impair the EU's negotiation positions in other policy fields. In conclusion, the article will develop some ideas for the further development of the Stockholm Programme, as its extension and advancement will be discussed throughout 2014.

\section{EU migration policy under altered circumstances}

The revolutionary wave weeping through North Africa and the Middle East in winter 2010/2011 was the first litmus test for the European Union's fundamentally revised external action structure. Initiated by the Lisbon Treaty on 1 December 2009, the creation of the double-hat position of the High Representative of the Union for Foreign Affairs and Security Policy and Vice-President of the European Commission (HR/VP), as well as head of the European External Action Service (EEAS), was only one important shift within the EU power structure. Making the EU Charter of Fundamental Rights compulsory for all EU action - including external relations - strengthened the framework for ensuring human rights through EU activity (Mink, 2012: 142). Though proclaimed in 2000, it was only Article 6 of the Lisbon Treaty that eventually defined the Charter's legal obligation. This Article also called for the EU's accession to the European Convention for the Protection of Human Rights and Fundamental Freedoms, thereby increasing the weight of humanitarian considerations in actions taken by the EU. In line with this, the Lisbon Treaty outlines in Article 21 the guiding 
principles upon which EU foreign policy must be built, namely 'democracy, the rule of law, the universality and indivisibility of human rights and fundamental freedoms, respect for human dignity, the principles of equality and solidarity, and respect for the principles of the United Nations Charter and international law'.

These principles gain particular relevance in the discussion about the treatment of irregular migrants and the EU's idea of 'third safe countries', namely, its strategy of externalizing and extraterritorializing 'a substantial part of their immigration policies [...] in exchange of substantial financial support' (Caillault, 2012: 133) unto countries such as Libya or Morocco. Detention centres were set-up along the Mediterranean coast, Frontex arranged for joint missions and trainings with personnel from the neighbourhood, and with the now much-debated European Border Surveillance System (EUROSUR) the 'pre-barrier territories' are set to become increasingly important to EU border control (Seiffart, 2012). As a result, for

the case of the EU's relations with North African countries, we have seen the emergence of an extensive system of security governance based on such instruments as readmission agreements, capacity building, export of surveillance technology, or information exchange. This stems from the fact that, in most of those countries, governments view themselves as guardians or policemen of European security (in return, of course, for certain favours) rather than defenders of their own citizens (Pawlak, 2012: 96).

Given the fact that even after the Arab Spring all countries in the EU's southern neighbourhood 'lack adequate guarantees, leave a far too large margin of appreciation to EU Member States and thus could necessarily lead to human rights violations' (Mink, 2012: 120f.), one would expect a drastic curtailing of these policies if EU decision-makers were to take the Lisbon Treaty seriously and respect human rights concerns as requested.

\subsection{Depoliticized relations and stronger autocracies as consequence of EU action}

The Lisbon Treaty also provides for an increased standing of the European Parliament (EP) and the Court of Justice of the EU (CJEU) in external affairs (Kaunert and Léonard, 2012: 16). Protocol 24 of the Lisbon Treaty stipulates that the CJEU 'has jurisdiction to ensure that in the interpretation and application of Article 6 [...] the law is observed by the European Union.'. Drawing primarily on Articles 77 to 79 and 218(6) of the Treaty on the Functioning of the European Union (TFEU), the EP 'has often voiced concerns over 
external cooperation objectives in the JHA field being implemented at the expense of human rights and civil liberties' (Trauner and Carrapico, 2012: 8). This clearly has made the work of EU diplomats in countries with dubious democratic standards more difficult. In the case of Egypt, for example, the EP called upon the Commission in March 2013 to stop the imbursement of EU support as long as the (then Morsi) government failed to meet minimum democratic standards (European Parliament, 2013). Discrete discussions between representatives from the EU and the Egyptian government now must grapple with the Sword of Damocles resulting from possible EP inquiries into what exactly is going on. Similar problems arise with other mediocre human rights performers. In consequence, partner governments will be more hesitant to share ideas and plans with the EEAS as absolute confidentiality cannot be assured and the risk of potentially compromising information reaching the public through EP scrutiny is enhanced (Senior staff member EU Delegation Cairo, 2012, personal communication).

In that sense, it is surprising that increased EP influence might contribute to a further de-politicization of the EU's relations with the Middle East and North Africa (MENA), as politically sensitive topics might be underaddressed in mutual negotiations. As a result of the disillusionment over the 'politicized' approach of the 1995 Euro-Mediterranean Partnership, the EU has concentrated its MENA relations more and more on 'technical cooperation' (Bauer, 2011: 420; Holden, 2011). In accordance with the EU Commission's own credo, ' $[\mathrm{t}]$ he most effective way of achieving change [in the region] is [...] a positive and constructive partnership with governments, based on dialogue, support and encouragement' (European Commission, 2001: 8), the construction of democratic façades was all too often celebrated as 'substantive progress'. A bit of increased electoral freedoms here, combined with considerable economic liberalization there were welcomed and praised as the Amman, Cairo, or Damascus Spring in the early 2000 s (Völkel, 2014: 266). For sure, the EU succeeded in assuring stability for itself, but it mainly failed in its aspirations to contribute to democratization and higher standards for human rights in the region. ${ }^{2}$

In fact, it soon became clear that EU attempts to 'transform the region into an area of peace, democracy, stability, and prosperity' (Noi, 2012:63) not only failed, but that these efforts actually helped strengthen authoritarian regimes in the region (Durac and Cavatorta, 2009:11ff.). Demands for serious political reforms in the MENA region were postponed 'with the fear that rapid democratic transformation would most probably lead to instability through violent upheaval and civil war, bringing anti-Western Islamist parties to power and perhaps causing a rise in terrorist activities' (Noi, 2012: 
73). Furthermore, with the creation of the Union for the Mediterranean (UfM) in 2008, the EU claimed 'a growing role of southern countries in its work in order to underline their co-ownership of the process' (Emara, 2010: 199). These measures ultimately gave these regimes more power (Reiterer, 2009: 322) and enhanced their hitherto low sense of ownership in the process (Comelli, 2010: 396). Though driven by good intentions, a negative outcome was that 'the institutional set-up elevates Arab regimes to become formal veto-players, and the prioritized policy areas have - from an Arab regime perspective - the advantage of being de-politicized and stripped of any ambitious macro-political goals such as democratization' (Schlumberger, 2011: 135). ${ }^{3}$

\subsection{EU migration policies: external affairs seen through the interior ministers' eyes}

The EU's focus on security diluted the concept of 'a ring of well-governed countries' (European Council, 2003: 8) to a concept of a ring of 'well-enoughgoverned countries.' ${ }^{4}$ By including immigration, asylum, and visa policies in the first pillar, thereby subsuming these policies to the EU's Area of Freedom, Security, and Justice (AFSJ), 'a strong emphasis was placed on the need to develop an "external dimension of JHA for the EU"' (Longo, 2013: 40; internal quote refers to Monar, 2004). One outflow of this was the 'quasi-militarization of European external borders with the erection of fences at Ceuta and Melilla, the creation of Frontex, the EU external border control agency, and the installation of an early-warning radar system, e.g. along the Spanish coast' (Caillault, 2012: 137).

This security-driven approach to migration ${ }^{5}$ (Bigo, 2009; Huysmans and Squire, 2009; Kaunert and Léonard, 2012: 2f.; Vollmer, 2011) also resulted from the fact that the two main actors in the conception of EU migration policy 'have been the European Commission's Directorate-General for Home Affairs (DG Home) and the Council's High Level Working Group on Migration and Asylum (HLWG)' (Carrera, 2013) but not external affairs actors. Primarily interior ministers led negotiations in the mid-1980s over the Schengen Agreement, a process that placed considerable emphasis on the internal security dimension of free border crossing. This set the overall tone of migration policy and even today, "EU Home Affairs policy makers remain very much in the driver's seat of the external dimensions of the EU's migration policy agenda, which de facto means Ministries of Interior-like actors playing at diplomats' (Carrera, 2013; emphasis in original). Consequently, in 2011, it was the DG Home which 
took the lead in drafting the Communication on a dialogue for migration, mobility, and security with the Southern Mediterranean countries, [...], while the EEAS was, to a large extent, sidelined in this decision-making process. It is not only in the internal preparation of the Dialogues, but also in the negotiations with third countries that DG Home Affairs has been taking a leading role. It is DG Home and not the EEAS that has led the majority of diplomatic missions abroad to promote and discuss the content of the Mobility Partnerships and the EU's 'insecurity approach' to migration from North Africa (Carrera, 2013).

The struggle between foreign and interior politicians within the EU framework also became visible in the aftermath of the political changes that took place in Egypt and Tunisia in early 2011. In efforts to reposition herself to the new situation, HR/VP Catherine Ashton presented the EU's new Mediterranean Strategy 'A Partnership for Democracy and Shared Prosperity with the Southern Mediterranean' (PfDSP) on 8 March 2011 (European Commission, 2011a). On 25 May 2011, the Commission tabled a comprehensive revision of the EU's European Neighbourhood Policy Strategy, 'A New Response to a Changing Neighbourhood' (European Commission, 2011b). Behind the façades of unified external action, however, Italy and France started struggling - mainly through their Interior Ministries in the Justice and Home Affairs Council and with reference to Article 2(2) of the Convention implementing the Schengen Agreement - with how to deal with increased inflows of irregular migrants from North Africa. Denmark began discussing the re-introduction of custom controls, while Germany, the Netherlands and others demanded the right to reinstate border controls. In short, some EU governments anticipated recanting one of the EU's central and most appreciated achievements, the abolishment of internal border controls. ${ }^{6}$

In line with the approach of depoliticizing its collaboration, the EU increasingly concentrated on economic cooperation with the MENA region. The general credo of liberalization was intended to sow the terrain for all cooperation activities in the economic sphere. Despite some successes, improved trade relations and EU-induced liberalization policies also brought economic problems to the MENA countries. These include a squeeze-out of the middle class, reduced social security, and the unfettered accumulation of wealth among the leading classes (Reynaert, 2011: 629f.). These economic inequalities have become, 'together with a lack of liberty, the root cause for the revolutions and the protests in the region' (Reynaert, 2011: 630). It was not by coincidence that " $\mathrm{t}$ ] he "Arab Spring" began in Tunisia and Egypt, two countries where new economic policies inspired by "orthodox" and "neoli- 
beral" recipes over the years had increasingly eroded the existing relatively egalitarian social contract and coalitions reflecting it' (Kienle, 2012: 549).

Hirschman's (1970) dictum of people protesting with either their feet or their voice was confirmed once again by the events in Tunisia, Egypt and Libya beginning in December 2010. People not only took out to the streets but also left their countries, making use of the collapsed border and coastal controls. Indeed, the year 2011 saw a dramatic increase of irregular migration from North Africa into the EU, especially from Libya and Tunisia, with skyrocketing numbers of asylum applications lodged in the EU especially by Tunisians ( $+911 \%$ in 2011 compared to 2010 ), Libyans (+293\%), and Egyptians $(+85 \%){ }^{7}$ However, scholars like Fargues (2011) stress that the rise in numbers was not as dramatic as politicians like to pretend, especially not in the long run. In 2012, the total number of detected illegal border crossings into the EU fell by 5o per cent compared to 2011, from c. 150,000 to c. 73,000 (Frontex, 2013: 5). With regard to the central Mediterranean area in particular, the decline was even greater at 82 per cent, from 59,00o to 10,379 (Frontex, 2013: 18), and in the western Mediterranean, the numbers decreased by 24 per cent to 6,397 , falling roughly the level of the years 2008 and 2010 (Frontex, 2013: 20). ${ }^{8}$

\subsection{Mobility partnerships and readmission agreements as questionable 'carrots' for third countries}

One of the most lucrative EU offers for the 'good performers' among the Arab transformation countries are mobility partnerships. The principal idea behind these mobility partnerships is to offer more access to Europe in exchange for improved border-protection cooperation, which includes the signing of readmission agreements. In addition to the 'advanced status' partner country Morocco, the Arab Spring shifted the spotlight on to Tunisia and Egypt as possible new mobility partnership addressees (Maroukis and Triandafyllidou, 2013: 2). Tunisia, motivated by the 'advanced status' promise, entered into negotiations and finally signed the mobility partnership on 3 March 2014 (European Commission, 2014). It then joined the circle of primarily Eastern European countries that had signed EU mobility partnerships, such as Moldova (2008), Georgia (2009) and Armenia (2011). In contrast, the Egyptian government directly refused the request (European Commission, 2013b: 12). Seeberg (2012:14) argues that

[t]he reason for the Egyptian decline has to do with the fact that the Egyptian authorities have stated that they cannot commit to any agreement as long as the new political leaders have been unable to take responsibility for the question. 
This reflects only one side of the coin. In fact, Egyptian representatives perceive the proposed mobility partnership, which aims to reach a readmission agreement, as benefitting the EU exclusively (Senior staff member League of Arab States, Cairo, 2012, personal communication). A readmission agreement would involve the concluding partners agreeing to readmit their own nationals, or third nationals that have moved through their territory, should they enter or stay irregularly in the agreement partner's territory. EU negotiators consider these agreements useful in cases 'of irregular migrants, whose itinerary, but not their identity, can be established. With readmission agreements in place, nationality may no longer be the decisive factor for return, if transit through a country can be proved' (Roig and Huddleston, 2007: 365).

For Egyptians, however, the full mobility partnership package is perceived as 'restricted, non-permanent and highly conditional' (Carrera et al., 2012: 13), as the hoped-for visa facilitation cannot be guaranteed by the EU (Roig and Huddleston, 2007: 376f.). This is indeed regrettable for both sides, as the current procedures for obtaining Schengen visas are for the educated Egyptian elite in particular expensive, complicated, and even humiliating. A visa reform especially for multiple travellers (business men, academics, also students) could make a real difference here (Senior faculty member Cairo University, 2012, personal communication). But all that has thus far been offered is that

[o]n 27 February 2012 the European Commission adopted a Decision establishing the list of supporting documents to be presented by visa applicants in Egypt. From 1 March 2012, all EU Member States require the same set of documents from visa applicants wishing to travel to the European Union (Schengen area). This measure is a huge simplification for the some 120,000 visa applicants in Egypt, who now no longer face differing requirements (European Commission, 2013b: 12).

Because the EU internal decision-making structure in the field of visa issuance is complicated and unpredictable (all Schengen member states have to agree, visa facilitations can be retracted on short note, etc.), these modest improvements make it only moderately more attractive for southern countries to engage in mutual mobility commitments.

If the EU wants to win southern countries' consent to readmission agreements and mobility partnerships, it must offer more than its migration portfolio. This could involve substantial and costly offers in other areas of development cooperation. Senegal, for instance, linked its readmission 
agreement negotiations with Spain to an additional $€_{15}$ million in development cooperation (Roig and Huddleston, 2007: 378). The example of Turkey, as discussed below, is also illustrative of this effect.

\section{Five paradoxes of the EU's Mediterranean migration policy}

Considering the general trend in EU migration policies (security-driven, little incentives for third countries), we can identify five paradoxes in the EU's migration policy towards third countries, meaning activities and behaviour that lead to counterproductive results. Each paradox supports the argument that the concentration on security within EU migration policy is the wrong approach to combating irregular migration, as it neither reduces the number of irregular migrants nor assures the necessary access to EU territory for legitimate asylum seekers. Furthermore, in pursuing this approach, the EU actually weakens its negotiation position in other policy fields by granting its negotiating partners leverage. Finally, the EU undermines its credibility as a human rights advocate that, in turn, makes it easier for autocratic rulers to argue against implementing minimum democratic standards in their countries.

\subsection{The EU chooses a sledgehammer to crack a nut. But it is far from hitting the nutshell}

The first paradox is that the EU is fighting the problem with the wrong means. Since having gone operational, the budget for Frontex has been increased from €19.6 million (in 2006) to €93.95 million in 2013 - an increase of almost $48 \mathrm{o}$ per cent. ${ }^{9}$ This budget is just in addition to the national expenses spent by EU Member States on border protection, which in many cases also underwent exorbitant increases. The Heinrich Böll Foundation calculates that the total costs for the EUROSUR programme will involve another $€_{318}$ million (in its least expensive version) to $€ 913$ million (in the most expensive version) in addition to annual operating costs (Hayes and Vermeulen, 2012: 51). Expenses for the multiple border control related initiatives under the $€ 1.4$ billion European Security Research programme, the European Defence Agency and similar initiatives have to be considered too. Hence, in the name of 'security', the EU and its member states have increased their border-protection spending by multiple-digit percentages, despite all the economic turbulence most European states have been subject to. 
While the militarization of EU borders through Frontex and the attendant exploding costs might be justified by the need to fight international crime (e.g., cross-border weapons and drugs smuggling, human trafficking), the same is not true for irregular migration, as most irregular migrants within the EU arrive with a valid tourist visa and then simply overstay (Triandafyllidou and Ambrosini, 2011: 271f.). Consequently, '[f] ocusing on border control seems particularly inappropriate given that most African irregular migrants actually enter Europe legally, subsequently overstay their visa, and only then become irregular in the end' (Caillault, 2012: 137). Mediterranean boat migration or Eastern European river crossings, meanwhile, make only for a minor share of irregular migration into the $\mathrm{EU}$ (De Haas, 2007: 4). According to data from the Italian interior ministry,

only $10 \%$ of the foreigners who resided illegally in Italy in 2002 had entered the country illegally by sea, while $15 \%$ had entered the country illegally by land, and $75 \%$ were overstayers [...]. The share of illegal arrivals by sea was estimated at $4 \%$ in 2004, $14 \%$ in 2005, $13 \%$ in the first six months of 2006 (Cuttitta, 2007:3).

Similarly, Coslovi (2007:2) speaks of 61 to 75 per cent overstayers among all irregular residents in Italy for the first half of the 2000s, and even Frontex (2013: 18) admits 'that overstaying is a very common modus operandi for irregular migration to the EU'. Even if one were to argue that Frontex military patrols help mitigate irregular migration, it does so at high costs for relatively little outcome, which means the EU principle of proportionality is clearly disregarded..$^{10}$

This critical finding can also not be refuted with the argument that

Frontex pursues a homogeneous border management practice rather less through practical cooperation in operations but rather through its risk analysis activities, as they serve to create - for the first time in the history of the European Union's external border - a unified image of that very border (Kasparek and Wagner, 2012: 190).

Paying €93.95 million primarily for 'risk analysis activities' is questionable by any standard. The EU Commission's Joint Research Centre, located in Ispra, Italy, with its seven scientific institutes, or the European University Institute in Florence and Fiesole would surely welcome a certain share of such funding and produce analyses of equal or better quality. 


\subsection{The EU pushes more people into clandestine migration}

Another paradox result was produced by the introduction of biometric Schengen visas in 2012. Martin (2012: 281) has shown that by obliging travellers to register in the upcoming Registered Travellers Programme, the EU is 'extending its capacity to control mobility far beyond its jurisdiction, gathering up personal data from ever more countries in the world'. Clearly, this poses legal questions for the EU. But it also creates another problem: it essentially nudges those non-EU nationals who enter the EU with the intent to stay irregularly (i.e., those persons planning to live illegally in the EU under any circumstance) to forfeit applying for a Schengen visa (and then overstay) and enter clandestinely through the Mediterranean (Member of the Secretariat of the European Parliament, Florence, 2012, personal communication). They therefore avoid having their fingerprints registered in an EU-wide database, which makes identifying their nationality much easier and therefore increases the risk of being sent back once found in Europe. In the absence of clear documentation, the long-lasting procedures involved with identifying an illegal migrant and proving nationality or origin increases a migrant's chances of remaining in Europe. As Düvell (2011: 293) pointed out,

a significant (unintended) effect of limiting regular immigration and restricting employment is that migration is driven into informal, shadow and niche activities. These findings show that despite the political intention of preventing and reducing irregular migration various legislations instead contribute to its emergence.

This implies that more fatalities will be the consequence, it seems the $\mathrm{EU}$ is creating the very irregular migrants it then tries to push back with massive investments in Frontex and upscale border protection technology. Unsurprisingly, at the EU's eastern border, 'many more migrants opted for clandestine entry (hiding in lorries or trains) during 2012 compared to 2011' (Frontex, 2013: 27). A certain share of these migrants can presumably be attributed to the introduction of biometric Schengen visa.

The introduction of biometric data has also been associated with the increasing number of desperate attempts to avoid documentation. Grant (2011: 148) tells the story of a young man residing illegally in the EU who 'used a lit cigarette to burn the fingerprints off his ten fingers [...] to prevent his prints being checked against migration databases, such as EURODAC, and to avoid return to a country of feared persecution."1 
A similar effect, namely the push of possible migrants from regular into irregular options, can occasionally be observed on the national level. For example, Italy's

misuse of the existing quota system tends to increase the chances of becoming a legal resident migrant for an undocumented migrant who is already in Italy, than for a potential migrant who is trying to gain legal access to the Italian labour market from abroad (Maroukis and Triandafyllidou, 2013:3).

Following the conclusion of the Egypt-Italy readmission agreement in 2007, some 5,00o Egyptian nationals illegally residing in Italy were legalised (Migration expert, Cairo, 2012, personal communication). This sent the message to people outside the EU that it was easier to enter Italy irregularly and hope for subsequent legalization than to enter by official means and apply for a regular work permit from the outset. Reliable numbers for the entire EU are difficult to assemble, but Rosenblum (2010: 1) speaks of approximately five million formerly irregular migrants since the 1980 s whose status has since been legalized within the EU. ${ }^{12}$

\subsection{The EU makes irregular migration more dangerous and contributes to higher death toll}

Frontex' successful narrowing of key migration routes in the Mediterranean through enhanced control of the shortest (and hence mostly favoured) transfer stretches is schizophrenic, as it must be presumed that it does not reduce the number of clandestine migrants, but simply diverts the routes. Already in 2006, a

briefing to the European Parliament concluded that efforts to curb the number of migrants trying to reach Europe had not led to a decrease in the number of irregular migrants; instead, they have had the effect of displacing migration from one place to another and were accompanied by an increasing number of fatalities at the EU's external borders (Grant, 2011: 140).

Given that full control of the entire Mediterranean area is impossible, closing up the shortest paths to EU entry, namely the Strait of Gibraltar between Morocco and Spain or the Strait of Sicily between Tunisia and Italy/Malta, has led to a diversion of migrants' routes and an extension of the transfer distances. For example, Kasparek and Wagner (2012:185) argue that 'Greece has become the main gate of irregular migration to Europe 
[...] is partially due to the closure of the routes in the Western Atlantic and Central Mediterranean'.

Spijkerboer (2007) reaches similar conclusions. Though the reliability of available data was (and still is) questionable, he argues that in the case of increased border controls and the closure of relatively unproblematic transit routes through the Mediterranean, 'rather than abandoning their plans to travel to Europe, these migrants had simply chosen more dangerous migration routes, which exposed them to even greater risks' (Grant, 2011: 140). The number of deadly incidents in the Mediterranean would therefore increase rather than decrease through intensified border controls.

Frontex representatives and supporters of strict border control on the side of the EU and the member states understandably see it differently, and proudly point to statistics showing how the number of irregular migrants in the Mediterranean has been reduced through increased control and the closure of the most popular boat routes. When, for example, the western and central Mediterranean routes were almost closed through increased surveillance activities,

Frontex recorded drops of some go per cent in the detection of irregular migration on the Central Mediterranean route to Malta and on the West African route to the Canary Islands. NGOs also reported steep reductions in the number of reported deaths at EU sea borders (Grant, 2011: 139).

However, those arguing these points overlook the fact that the reduced numbers counted in the areas under high control were not offset or even outweighed by higher death toll numbers in the high seas beyond their control. In principle, juggling with statistics regarding refugee numbers in the Mediterranean is difficult. For example, after the RABIT operation took place at the Greek-Turkish border between November 2010 and March 2011, 'Frontex did report a decrease in numbers of irregular border crossings. However, as this might also be due to the heavy winter, this particular statistical data does not allow for a rigid interpretation' (Kasparek and Wagner, 2012: 188).

In effect, passage routes are growing in length and are increasingly more dangerous for refugees. More fatalities must be expected. Or, as Frontex (2013:5) states with regard to the 2012 Greek border-protection upgrade, ' $\mathrm{t}$ ] here remains the risk of resurgence of irregular migration, since many migrants may be waiting for the conclusion of the Greek operations before they continue their journey towards Europe'. If that is the case, then once again considerable sums are being spent for a hardly satisfying outcome. 
In addition, diverting routes through the Mediterranean involves higher financial costs for the refugees as professional traffickers demand higher fees. Human trafficking thus becomes an even more lucrative activity for traffickers - as a result of EU policy.

\subsection{EU Readmission Agreements result from internal requirements, not external necessities}

Another paradox involves the EU's special keenness on concluding EU Readmission Agreements (EURA) with third countries. 'Since 1999, when competence in this area was conferred on the European Community, the Council has issued negotiating directives to the Commission for 18 third countries' (European Commission, 2011c: 2 ). These 18 countries mainly comprise potential future EU Member States (Western Balkans and Eastern Europe) in line with the EU's 'concentric circles' model (Panizzon, 2012: 102f.), but also illustrative countries such as Georgia, Russia, Pakistan, or Hong Kong. ${ }^{13}$

Once the Commission is tasked with negotiating a readmission agreement with third countries, all EU Member States should stop any national negotiations conducted in parallel. However, this is in practice rather clumsy, as the interpretation of competence-sharing differs among various EU members (Roig and Huddleston, 2007: 369). The Lisbon Treaty (Article 79(3), combined with Article 79(1) and 4(2)(j)) left the exact division of competences in the area or readmission agreements unspecified, and it is up to further legal interpretations to decide who should be assigned with which negotiation powers and which decision competences (Panizzon, 2012: 124ff.).

So far, third countries clearly prefer concluding readmission agreements with individual EU Member States over the EU. There are two key reasons for this:

Given the higher developmental impact of bilateral migration agreements, which unlike EURAs, offer labour market access quotas in exchange for cooperation on readmission we find there are justified reasons why migrant source countries often prefer such bilateral migration agreements over EURAs. The preference for bilateralism, however, can also be explained by the weak obligations to uphold the human rights of readmitted citizens and third-country nationals (TCN) or the total absence of such rights guarantees (Panizzon, 2012: 104). 
In 2013, the five North African countries Morocco, Algeria, Tunisia, Libya and Egypt had readmission agreements with five EU Member States in different states of negotiation (cf. table 1). The data reveal that there is close cooperation against irregular migration especially in the western Mediterranean (Morocco with Portugal and Spain) and the central Mediterranean (Algeria, Libya and Tunisia with Italy; Malta is negotiating with all close southern neighbours but has to date not successfully concluded negotiations).

Table 1 Agreements linked to readmission between northern and southern Mediterranean countries ${ }^{14}$

\begin{tabular}{|c|c|c|c|c|c|}
\hline & Algeria & Egypt & Libya & Morocco & Tunisia \\
\hline Cyprus & - & - & - & - & - \\
\hline France & $\begin{array}{l}\text { EL 1984-1994 } \\
\text { PC s 2003 }\end{array}$ & $n$ since $2007^{15}$ & $f 2007$ & $\begin{array}{l}\text { EL 1983-1993 } \\
\text { PC f } 2001\end{array}$ & $\begin{array}{l}\text { EL 1984-1994 } \\
\text { f2009 }\end{array}$ \\
\hline Greece & - & PC $f 2000$ & - & - & PC s 1990 \\
\hline Italy & $\begin{array}{l}\text { f2006 } \\
\text { PC s } 2009\end{array}$ & $\begin{array}{l}P C f 2000 \\
f 2007\end{array}$ & $\begin{array}{l}\text { AA s } 2000 \\
\text { AA s } 2003 \\
\text { MU s } 2006 \\
\text { PC s } 2007 \\
\text { MU s } 2011 \\
\text { EL } 2012\end{array}$ & s 1998 & $\begin{array}{l}\text { f } 1999 \\
\text { PC s } 2003 \\
\text { AA s } 2009 \\
\text { s } 2011\end{array}$ \\
\hline Malta & n since 2001 & $n$ since 2001 & $\begin{array}{l}\mathbf{P C} 1984 \\
\mathrm{n} \text { since } 2001\end{array}$ & - & $n$ since 2001 \\
\hline Portugal & - & - & - & f2004 & - \\
\hline Spain & Pf 2004 & - & - & $\begin{array}{l}\text { PA } 1992 \\
\text { MU s } 2003 \\
\text { MU s } 2007 \\
\text { PC f } 2012 \\
\text { f } 2012 \\
\text { (of the } 1992 \\
\text { agreement) }\end{array}$ & - \\
\hline
\end{tabular}

Given the lack of incentives the EU has to offer while trying to sign readmission agreements (due to its dependence on member states' willingness to implement the benefits promised to the third countries), it is no surprise that no other country could have been convinced to enter into negotiations so far.

[I]t is not so much the EU approach to a third country that determines the success or failure of EU external migration policy. Instead, the domestic 
preferences of the third country concerned condition whether or not its government will choose to cooperate with the EU on migration issues' (Reslow, 2012: 394).

Egypt's hesitation towards an EU readmission agreement (see chapter 2.3) is rooted in its unsatisfying experiences with Italy. The readmission agreement between both countries, signed in November 2005 and put into force in 2007, has been poorly implemented so far:just a few dozens of Egyptians get readmitted per month, a number that deems small compared to the thousands of Egyptians believed to be residing illegally in Italy. As there are almost no Italians who live illegally in Egypt, the benefit for the Egyptian government is minimal. In an attempt to provide the Egyptian government an incentive to conclude the agreement, the Italian government offered to accept 8,0oo qualified Egyptian workers with a proper work permit in Italy. So far, however, only around 16o Egyptians have been successfully placed, mainly because Italy demands standards that Egypt is unable to fulfil, such as HACCP hygienic certificates for gastronomy personnel - which are not applied in Egypt (Migration expert, Cairo, 2012, personal communication).

Hence, the mere existence of a readmission agreement does not necessarily mean that it is applied in practice. For example, despite an existing readmission protocol between Turkey and Greece, only 1,281 Turks were effectively readmitted between 2006 and 2010, though Greece has presented requests for 62,816 people (Triandafyllidou and Ambrosini, 2011: 258f.).

Among the Mediterranean countries, the EU Commission has negotiated only with Morocco (since April 2003), Tunisia (since 2011), and Turkey (since May 2005). In addition, the Commission received a mandate from the Council to start negotiations with Algeria in November 2002, but which have never started. Negotiations with Tunisia were quick and smooth (see chapter 2.3), but negotiations with Morocco and Turkey have been long and thorny. This was mainly due to two reasons: For one, both governments demanded linking the signature of the readmission agreement with a visa facilitation agreement (a request that was also made by almost all governments, incl. Algeria; yet, only 11 of the 18 EU Readmission Agreements (concluded or still under negotiation) indeed contain visa liberalization $\left.{ }^{16}\right)$. But here, the Commission cannot make substantial promises, as visa facilitation must be concluded by the Council, and member states have been far from being united on the idea of easing access for citizens from the countries concerned. Devisscher (2011: 93) observes that in EU readmission negotiations, '[w] here measures have been taken, they are not legally binding and where they are, commitments on the part of the Union are weak, while in parallel 
imposing strict obligations on the third country'. Turkey's government has repeatedly emphasized that it is not willing to implement the readmission agreement with the EU even after its signature if visa facilitation is not included (Today's Zaman, 2013). Hence, despite recent successes, with the signatures of the Turkish government under the readmission agreement on 16 December 2013 and Morocco's signature under an even more encompassing Migration and Mobility Partnership on 7 June 2013, there is plenty of due cause for scepticism that the agreements will be put into effective practice (Coleman, 2009: 27ff.).

Another arguable paradox might be seen in the fact that EU Member States have been willing to unify their efforts to combat irregular migration (excepting the examples elucidated above) but have failed to forge a common position on how best to steer regular migration. The Blue Card initiative, proposed by the Commission in 2007 and specified by the Council's Directive 2009/50/EC in May 2009, aims to improve incentives for regular labour immigration but suffers from 'the many "mayclauses" that provide the member states with wide discretion and, as a consequence, reduce the "attractiveness" as initially framed by the Commission' (Eisele, 2013: 2). Until the EU Commission proposes more clear incentives for partner countries, better results in migration partnership negotiations with third countries remain unlikely. The Commission's next interim report on the Blue Card initiative, expected for summer 2014, will hopefully bring some improvement here.

Financial expectations also play a role. During its negotiations with the EU, Turkey wanted 'the readmission agreement to include strong funding from the EU, mirroring similar funding that is available to EU Member States under the "resettlement policies" within the European Refugee Fund' (Kasparek and Wagner, 2012: 186). However, the Commission is limited in terms of its capacity to make such offers, as

[t]he only instrument that could in principle provide this additional funding to third countries is the Thematic Programme for cooperation in the areas of migration and asylum. But the Thematic Programme has a very limited budget (approximately 54 million EUR annually) and is designed to cover cooperation activities world-wide, meaning that the resources potentially available for a specific third country are very small (European Commission, 2011c: 7 ).

Many southern Mediterranean countries have also raised concerns regarding the mandatory 'Third Country Nationals' (TCN) clause that obliges 
the partner countries to not only readmit their own nationals but also citizens from third countries that came into the EU via their territory. Meanwhile, the governments argue that they cannot be held responsible for the behaviour of citizens from other countries, and the EU argues that TCN is necessary as countries are also main transit countries for irregular migrants from other countries. Without such a clause, readmission agreements made little sense for the EU (European Commission, 2011c: 9). However, it is important to note that even the Commission itself criticizes the lengthy process of TCN negotiations and also questions the pressure coming from the member states at that point:

It has been Commission's experience that by the time the third country finally accepts the principle of a TCN clause, a lot of time will already have been lost and further concessions are then necessary in order to agree on the precise language and preconditions of the clause, often to the detriment of its effectiveness. To maintain such effectiveness a use of appropriate leverage would have been useful in cases when it is particularly relevant for the EU to have a TCN clause included. Readmission of own nationals should typically not require important incentives. Interestingly, MS' bilateral readmission agreements seldom include a TCN clause (mainly where there is a common land border). Yet MS always demand a TCN clause at EU level (European Commission, 2011c: 9).

The high costs and effort incurred by negotiations, coupled with the fact that most readmission activities around the Mediterranean are already subject to bilateral agreements (though these are often implemented rather loosely) raise the question as to why the EU needs to engage in all these negotiations. The reasons for this are related to the institutional grow th of the EU as a political entity. Since the Treaty of Amsterdam, which places asylum and visa issues within the European Community's sphere of responsibilities, since the implementation of the Schengen Agreement and later the Stockholm Programme in 2009 and, most recently, since the EU level has been afforded more power in external affairs through the creation of the HR/VP and the EEAS, it is only logical that the EU should also work towards a common border-protection policy and address the return of irregular migrants. The creation of Frontex in 2004 is the most visible manifestation of this idea.

However, this is neither the problem of the negotiation partners, nor does it find the unqualified support of all EU Member States. Greece, Italy, and Malta, each of which are at the forefront of clandestine migration in 
the central Mediterranean, have had problems with the unified borderprotection approach. In particular, they have voiced concerns about their national agreements and border-protection measurements being challenged (Kasparek and Wagner, 2012). This current 'dual' state of affairs, in which readmission agreements are pursued at both the EU and individual member-state level allows participating third countries to play each level against the other. Thus, as long as EU competences in this regard remain poorly defined, the EU will continue to undermine its noble efforts to speak with one voice in external relations.

\subsection{The EU is losing ground in very important negotiations}

The EU's insistence on negotiating and reaching readmission agreements leads to a fifth paradox that deserves consideration here: The EU unnecessarily loses arbitration ground in other negotiations. As happened between Senegal and France, "[r] eadmission has already proven to be an obstacle in bilateral agreements and almost caused the failure of the negotiations on the accord de gestion concertée des flux migratoires' (Reslow, 2012: 408).

This problem also arises in EU negotiations. The insistence on things that the partner government cannot (or does not want to) fulfil casts long shadows on parallel negotiations. In the wake of the Arab Spring, for example, people in North Africa often felt that the EU perceived them as "'areas of risks", not partners or friends' (Bauer, 2011: 425). As a result, a sense of mistrust regarding the EU's real intentions spread among North African populations, and complaints were often expressed about the EU preaching democracy but meaning stability.

The EU's insistence on 'unfulfillable' conditions and requests make an already difficult situation even more difficult for the negotiators on both sides, and unnecessarily so. This is even more astonishing when considering the 'relevance' of migration in the overall negotiations between the EU and individual partner countries. Egypt, for example, is not a significant country of origin, though ' $[\mathrm{r}$ ] ecently a rise in migration to Europe - mostly irregular - especially Italy and France, has been recorded' (Badawy et al., 2013: 75). Despite having a population larger than that of all other four North African states combined (c. 86 million in Egypt, c. 80 million in Algeria, Libya, Morocco and Tunisia), only 224,122 Egyptians reside in the EU, compared to 4,464,963 Egyptian migrants in total who mainly live and work in the Arab Gulf countries. This means that only five per cent of all Egyptian migrants live in the EU, most of them in Italy (Bartunkova and Völkel, 2010: 14). This is in clear contrast to Algeria, Morocco and Tunisia from where roughly $90 \%$ of migrants make their life in the EU (cf. table 2 ). 
Also, in absolute numbers, there are clearly fewer Egyptians than people from the Maghreb living in Europe. Overall, with a total of 4.6 million, North Africans comprise approximately 20 per cent of the total 23 million immigrants who live in the EU.

Table 2 Emigration from North Africa to the EU compared to total numbers (Fargues, 2013: 6)

\begin{tabular}{l|c|c|c|c|l|c|}
\hline & Algeria & Egypt & Libya & Morocco & Tunisia & \multicolumn{1}{|l|}{ TOTAL } \\
\hline in EU & 877,398 & 224,122 & 66,344 & $3,056,109$ & 414,077 & $4,638,050$ \\
\hline overall & 961,850 & $4,464,963$ & 100,565 & $3,371,979$ & 466,595 & $9,365,952$ \\
\hline \% in EU & $91.2 \%$ & $5.0 \%$ & $66.0 \%$ & $90.6 \%$ & $88.7 \%$ & $49.5 \%$ \\
\hline
\end{tabular}

Given these relatively low numbers, it is not surprising that Egypt has not pursued a stringent migration policy in its relations with the EU in particular. Indeed, the Egyptian government has, in principle, been more interested in technical than 'political' cooperation (Senior staff member Egyptian Ministry of International Cooperation, Cairo, 2012, personal communication). With the demise of the Mubarak regime and the series of interim governments that followed, any migration-steering measures were put on ice. In the absence of a long-term perspective and as short-term domestic topics dominated the political agendas, negotiations with the EU came to a halt (Senior faculty member American University in Cairo, 2012, personal communication) ${ }^{17}$

The only migration-related issues relevant for Egypt are the high levels of remittances from workers abroad and the ease of the domestic job market through the 'export' of labour. Though scientific evidence for their exact effectiveness is difficult to furnish (Nassar, 2008), remittances are the third biggest source of income for the Egyptian budget, after revenues from the Suez Canal and tourism, totalling up to 4 per cent of GDP (Bartunkova and Völkel, 2010: 15). As tourism drops to unprecedented low record numbers, and as the income generated by the Suez Canal declines (Egypt Independent, 2013), the income from Egyptians abroad is growing in importance. However, because most remittances are arriving from guest workers in Gulf countries, it is unlikely that the Egyptian government will be very keen on regulating Mediterranean migration into the EU in the near future - even if (according to opinion polls) more Egyptians are expressing the desire to emigrate during this period of political and economic turmoil.

Finally, the will to cooperate with southern Mediterranean countries in the fight against irregular migration bears some risks for the EU as it attempts to strengthen and support human rights. According to the European 
Commission (2011c: 12), readmission agreements with countries exhibiting a poor human rights record lead to massive criticism and major policy dilemmas. To resolve this problem, the Commission recommended introducing 'a suspension clause [in the readmission agreements] for persistent human rights violations in the third country concerned' (European Commission, 2011c: 12). However such safeguard clauses would generate the next paradox: Given that none of the regimes in North Africa adequately guarantee respect for human rights, with the possible exception of Tunisia, why should the EU run the risk of concluding agreements whose implementation it cannot guarantee? Moreover, why should the EU load another burden on its shoulder, as it would have to defend its cooperation in the fight against irregular migration with backhanded governments? The European Parliament's move in early 2013 to stop any support for Egypt due to its questionable performance in terms of ensuring democratic standards has clearly shown what the consequences of such an approach are: constant worry and a constant source of disputes. Given the already poorly satisfying results of EU-MENA relations and negotiations, this approach would constitute an unnecessary stumbling block that hinders rather than helps.

\section{Conclusions}

In 2014, the last year of the Stockholm Programme, much is at stake with the EU's migration policy. Many steps have been taken by the European Commission and the EU Member States that have produced, at best, questionable results:

Instead of reducing migration, intensified border controls have led to a rise in irregular migration, the use of new and more dangerous migration routes, thus increasing the risks and costs for the migrants involved, and leasing to the professionalization of smuggling methods (Caillault, 2012: 137f.).

The Commission has tried to react quickly to the altered circumstances in its Arab neighbourhood since 2011 (Teti, 2012). Nonetheless, it is still struggling to find the best strategy to improve cooperation with the southern Mediterranean countries in the field of border protection (Völkel, 2014). The Commission's Communication on the Global Approach to Migration and Mobility of November 2011 is indicative of this struggle. It proposes a Common Agenda on Migration and Mobility as a light alternative' for those 
countries that are not willing to sign a full-fledged mobility partnership. Clearly, the EU wants a lot, but it has little to offer (Reslow, 2012: 414).

It is clear that when concentrating on border protection alone, 'the effectiveness of both unilateral and multilateral policies to regulate forced migration flows is limited' (Thielemann, 2012: 21). But despite this insight, continuing to treat migration from North Africa as a potential security threat 'has damaged the EU's credibility in terms of the promotion of democracy and human rights' (Freyburg, 2012: 141). The EU's support of North African dictators for the sake of stability has damaged its reputation among the Arab public and has negative consequences for its role as a political power and peace broker in the region. Credibility is crucial for diplomatic success (Völkel, 2008: 19f.), and the EU's credibility has suffered considerably due to the EU's over-emphasis on Arab (and sub-Saharan) migrants as a potential security threat. In short, the EU's pursuit of domestic interests has effaced its diplomatic effectiveness in migration policy.

So, what is needed? For one, migration must not be perceived through the lens of security interests exclusively. The EU, with its demographic problems, should surely see migration first and foremost as an opportunity to compensate for the lack of workers. However, the continuing growth of populist movements and right-wing parties in Europe will make this difficult. Even more importantly, there is an urgent need in these times of European crisis to conduct honest and sober discussions about the risks and opportunities inherent to migration.

Second, the ongoing humanitarian catastrophe in the Mediterranean with thousands of lives lost at sea each year should prompt a serious rethinking of existing practices. The trend in recent years towards tightening rather than loosening visa policies is clearly misguided and wrong-headed. All too often, this approach simply compels individuals to choose irregular entry into the $\mathrm{EU}$ and does not lead to a factual reduction of influx numbers.

Third, it is time for concrete improvements in immigration policy to be made by EU and member-state decision-makers. Hopefully, revision talks about the Stockholm succession programme will allow for the Blue Card initiative to be fully implemented. Also, the competence dispute in the field of readmission agreements between the Commission and member states must be clarified.

Finally, the EU can make use of the existing stock of tools at its hands to help improve the performance of North African decision-makers in the field of migration. Awareness-raising and capacity-building efforts for midlevel public administration is a worthy initiative, especially with regard to reintegration programmes for returning (irregular as well as regular) 
migrants (Senior staff member IOM Cairo, 2012, personal communication). Suitable offers are available through TAIEX and Twinning but have yet to find resonance among potential partners (Senior staff member Ministry of International Cooperation Cairo, 2012, personal communication). Raising awareness about how to make use of such campaigns is therefore advisable here.

\section{Acknowledgements}

I am deeply grateful to the valuable suggestions and comments made by Chantal Lavallée, Christian Kaunert, Mohamed Limam and two anonymous reviewers. Thank you for your insights and time!

\section{Notes}

1. Article 6 TEU states that the EU 'recognises the rights, freedoms and principles set out in the Charter of Fundamental Rights'.

2. Freyburg (2012) has shown for the case of Morocco, that the EU, by externalizing its migration policy regime onto countries south of the Mediterranean, "exports" three core principles of democratic governance, namely transparency, accountability, and participation (to different extents, though).

3. The predominant concentration of UfM actors on the Israel/Palestine conflict, leading to the paralyzation of almost all UfM activities, can be seen as illustrative evidence.

4. Kausch and Youngs (2009: 967) speak of 'firmly governed states'.

5. Interestingly enough, migration policy aspects are listed in EU country progress reports under headline 5: Cooperation on Justice, Freedom and Security, and not under the chapters 'Political Dialogue' or 'People-to-People contacts', where migration could also be very well subsumed.

6. For example, the Netherlands decided to reinstall surveillance cameras along the Dutch borders (Rettman, 2012).

7. UNHCR 2012 data. It must be noted that in absolute terms, most asylum applications in 2011 of Mediterranean countries came from Syria $(6,725)$, followed by Tunisia $(5,248)$ and Algeria $(4,062)$. Libya $(2,710)$ and Egypt $(1,994)$, meanwhile, remained of only minor importance.

8. Despite the decreasing immigration numbers from North Africa, the European Commission (2013a: 3) noted that '[w]hile the total number of asylum applications remained well below the peak of 425000 in 2001, there was an increase of $9.7 \%$ compared to 2011 in the total number of asylum applicants in 2012, amounting to just over 330000 , primarily resulting from an increased influx of asylum seekers from Syria'.

9. See the Frontex budget data at http://www.frontex.europa.eu/assets/About_Frontex/ Governance_documents/Budget/Budget_2013.pdf(last visited 2 May 2013).

10. See on Immigration Detention and Proportionality also Flynn (2011).

11. EURODAC 'is a database containing the fingerprints of asylum-seekers, which is used to ascertain whether (and in which EU Member State) a given asylum-seeker has already 
applied for asylum in the EU. It has been operational since January 2003' (Kaunert and Léonard, 2012: 11).

12. Though it is unclear how many of them were simply turned into regular immigrants through, for instance, the accession of their home country as new member state to the EU.

13. See the complete list in European Commission (2011c: $2 \mathrm{ff}$.).

14. Data as of February 2013, taken from the Return Migration and Development Platform (RDP), http://rsc.eui.eu/RDP (accessed 2 August 2013).

15. This date is not included in the RDP database but accrues from Mourad (2008).

16. $\mathrm{cf}$. the list at http://ec.europa.eu/dgs/home-affairs/what-we-do/policies/borders-and-visas/ visa-policy/index_en.htm (accessed 8 April 2014).

17. However, it seems that the government under President Mohamed Morsi has recognized the relevance of (regular) migration for the country's development, as in 2012 Egypt 'started preparations for a household survey on migration, to be carried out in 2013' (European Commission, 2013b: 11). The toppling of Morsi on 3 July 2013 has finished this enterprise for the moment.

\section{References}

Badawy, T., Nassar, H., Sika, N. \& Shafie, S. (2013). Egypt. In: Fargues P (ed.) EU Neighbourhood Migration Report 2013. Florence: European University Institute, 73-86. Available at http:// www.migrationpolicycentre.eu/migration-report (accessed 23 July 2013).

Bauer, P. (2011). The Transition of Egypt in 2011: A New Springtime for the European Neighbourhood Policy? Perspectives on European Politics and Society, 12(4): 420-439.

Bartunkova, I. \& Völkel, J.C. (2010). Egypt. In: Kausch, I. \& Meininger, K. (eds.) Analysis of Mobility Management Systems in Technical Cooperation Partner Countries. Eschborn: Deutsche Gesellschaft für Technische Zusammenarbeit (GTZ), 11-15. Available at http://www2.gtz. de/dokumente/bib-2010/gtz2010-0496en-mobility-management.pdf(accessed 6 April 2014).

Bigo, D. (2009). Immigration Controls and Free Movement in Europe. International Review of the Red Cross, 91(875): 579-591. Available at http://www.icrc.org/eng/assets/files/other/ irrc-875-bigo.pdf (accessed 6 April 2014).

Caillault, C. (2012). The Implementation of Coherent Migration Management through IOM Programs in Morocco. In: Geiger, M. \& Pécoud, A. (eds.) The New Politics of International Mobility. Migration Management and its Discontents. Osnabrück: Institut für Migrationsforschung und Interkulturelle Studien, 133-154.

Carrera, S. (2013). The 'Arab Spring' and EU's Immigration Policy: A Critical Sociology on the Global Approach to Migration and Mobility. Washington: Middle East Institute. Available at http:// www.mei.edu/content/arab-spring-and-eus-immigration-policy-critical-sociology-globalapproach-migration-and (accessed 15 April 2013).

Carrera, S., den Hertog, L. \& Parkin, J. (2012). EU Migration Policy in the Wake of the Arab Spring - What Prospects for EU-Southern Mediterranean Relations? MEDPRO Technical Report 15. Brussels: Centre for European Policy Studies. Available at http://www.medpro-foresight. eu/system/files/MEDPRO\%20TR\%20No\%2015\%2oWP9\%2oCarrera.pdf(accessed 15 April 2013).

Coleman, N. (2009) European Readmission Policy: Third Country Interests and Refugee Rights. Leiden: Brill.

Comelli, M. (2010). Sub-regional Cooperation Around the Mediterranean and the Role of the EU. European Foreign Affairs Review, 15(3): 385-401. 
Coslovi, L. (2007). Brevi Note Sull'Immigrazione via Mare in Italia e in Spagna. Rome: Centro Studi di Politica Internazionale. Available at http://www.cespi.it/PDF/mig-mare.pdf (accessed 27 April 2014).

Cuttitta, P. (2007). The Changes in the Fight Against Illegal Immigration in the Euro-Mediterranean Area and in Euro-Mediterranean Relations. Genoa: University. Available at http://www. libertysecurity.org/article1293.html (accessed 27 April 2014).

De Haas, H. (2007). The Myth of Invasion. Irregular Migration from West Africa to the Maghreb and the European Union. IMI Research Report. University of Oxford: International Migration Institute. Available at http://www.imi.ox.ac.uk/pdfs/Irregular\%2omigration\%2ofrom\%2o West\%2oAfrica\%20-\%2oHein\%2ode\%2oHaas.pdf (accessed 27 April 2014).

Devisscher, P. (2011). Legal Migration in the Relationship between the European Union and ACP Countries: The Absence of a True Global Approach Continues. European Journal of Migration and Law, 13(1): 53-94.

Düvell, F. (2011). Paths into Irregularity: The Legal and Political Construction of Irregular Migration. European Journal of Migration and Law, 13(3): 275-295.

Durac, V. \& Cavatorta, F. (2009). Strengthening Authoritarian Rule through Democracy Promotion? Examining the Paradox of the US and EU Security Strategies: The Case of Bin Ali's Tunisia. British Journal of Middle Eastern Studies, 36(1): 3-19.

Egypt Independent (2013) Suez Canal Revenues Down Four Percent since January.31 July. Available at http://www.egyptindependent.com/news/suez-canal-revenues-down-four-percentjanuary (accessed 3 August 2013).

Eisele, K. (2013). Why Come Here if I Can Go There? Assessing the 'Attractiveness' of the EU's Blue Card Directive for 'Highly Qualified' Immigrants. CEPS Paper in Liberty and Security in Europe 6o. Brussels: Centre for European Policy Studies. Available at www.ceps.eu/ceps/ dld/8495/pdf (accessed 27 April 2014).

Emara, K. (2010). Is Sarkozy's Union for the Mediterranean Going to Work? In: Bindi, F. (ed.) The Foreign Policy of the European Union: Assessing Europe's Role in the World. Washington: Brookings Institution, 197-200.

European Commission (2001). The European Union's Role in Promoting Human Rights and Democratisation in Third Countries. Communication from the Commission to the Council and the European Parliament. COM(2001) 252 final. Brussels: European Commission. Available at http://eur-lex.europa.eu/LexUriServ/LexUriServ.do?uri=COM:2001:0252:FIN:EN:PDF (accessed 30 April 2013).

European Commission (2010). Delivering an Area of Freedom, Security and Justice for Europe's Citizens. Action Plan Implementing the Stockholm Programme. Communication from the Commission to the European Parliament, the Council, the European Economic and Social Committee and the Committee of the Regions. COM(2010) 171 final. Brussels: European Commission. Available at http://eur-lex.europa.eu/LexUriServ/LexUriServ. do?uri=COM:2010:0171:FIN:EN:PDF (accessed 5 July 2013).

European Commission (2011a). A Partnership for Democracy and Shared Prosperity With the Southern Mediterranean. Joint Communication to the European Council, the European Parliament, the Council, the European Economic and Social Committee and the Committee of the Regions. $\operatorname{COM}(2011) 200$ final. Brussels: European Commission. Available at http:// eeas.europa.eu/euromed/docs/com2011_20o_en.pdf (accessed 28 March 2013).

European Commission (2011b). A New Response to a Changing Neighbourhood. Joint Communication to the European Parliament, the Council, the European Economic and Social Committee and the Committee of the Regions. $\operatorname{COM}(2011) 303$. Brussels: European Commission. Available at http://ec.europa.eu/world/enp/pdf/com_11_303_en.pdf (accessed 28 March 2013). 
European Commission (2011). Evaluation of EU Readmission Agreements. Communication from the Commission to the European Parliament and the Council. COM(2011) 76 final. Brussels: European Commission. Available at http://eur-lex.europa.eu/LexUriServ/LexUriServ. do?uri=COM:2011:0076:FIN:EN:PDF (accessed 3 April 2013).

European Commission (2013a). 4th Annual Report on Immigration and Asylum (2012). $\operatorname{COM(2013)}$ 422 final. Brussels: European Commission. Available at http://ec.europa.eu/dgs/homeaffairs/e-library/documents/policies/immigration/general/docs/4th_annual_report_on_immigration_and_asylum_en.pdf (accessed 7 April 2014).

European Commission (2013b). Implementation of the European Neighbourhood Policy in Egypt. Progress in 2012 and recommendations for action. SWD(2013) 89 final. Brussels: European Commission. Available at http://eur-lex.europa.eu/LexUriServ/LexUriServ. do?uri=SWD:2013:0089:FIN:EN:PDF (accessed 3 August 2013).

European Commission (2014). EU and Tunisia Establish Their Mobility Partnership. IP/14/208. Brussels: European Commission. Available at http://europa.eu/rapid/press-release_IP-14208_en.htm (accessed 6 April 2014).

European Council (2003). A Secure Europe in a Better World. European Security Strategy. Brussels: European Council. Available at http://www.consilium.europa.eu/uedocs/cmsUpload/78367. pdf (accessed 30 April 2013).

European Council (2010). The Stockholm Programme - An Open and Secure Europe Serving and Protecting Citizens. 2010/C 115/o1. Brussels: European Council. Available at http://eur-lex. europa.eu/LexUriServ/LexUriServ.do?uri=OJ:C:2010:115:0001:0038:en:PDF (accessed 3o May 2013).

European Parliament (2013). Egypt: No EU Financial Support If No Progress on Democracy, MEPs Say. Press information. 14 March. Available at http://www.europarl.europa.eu/pdfs/news/ expert/infopress/20130308IPRo6308/20130308IPRo6308_en.pdf (accessed 30 May 2013).

Fargues, P. (2011). Voice After Exit: Revolution and Migration in the Arab World. Washington: Migration Policy Institute. Available at http://www.migrationinformation.org/Feature/ display.cfm?ID=839 (accessed 1 May 2013).

Fargues, P. (ed.) (2013). EU Neighbourhood Migration Report 2013. Florence: European University Institute. Available at http://www.migrationpolicycentre.eu/migration-report (accessed 23 July 2013).

Flynn, M. (2011). Immigration Detention and Proportionality. Global Detention Project Working Paper 4. Available at http://www.globaldetentionproject.org/fileadmin/publications/ GDP_detention_and_proportionality_workingpaper.pdf(accessed 7 Aug. 2013).

Freyburg, T. (2012). The Janus Face of EU Migration Governance: Impairing Democratic Governance at Home - Improving It Abroad? European Foreign Affairs Review, 17(2 Special Issue): 125-142.

Frontex (2013). Annual Risk Analysis 2013. Warsaw: Frontex. Available at http://www.frontex. europa.eu/assets/Publications/Risk_Analysis/Annual_Risk_Analysis_2013.pdf (accessed 3 May 2013).

Grant, S. (2011). Recording and Identifying European Frontier Deaths. European Journal of Migration and Law, 13(2): 135-156.

Hayes, B. \& Vermeulen, M. (2012). Borderline - The EU's New Border Surveillance Initiatives. Assessing the Costs and Fundamental Rights Implications of EUROSUR and the "Smart Borders" Proposals. Berlin: Heinrich Böll Foundation. Available online at https://www.boell.de/sites/ default/files/DRV_120523_BORDERLINE_-_Border_Surveillance.pdf (accessed 28 April 2014).

Hirschman, A. (1970). Exit, Voice, and Loyalty. Responses to Decline in Firms, Organizations, and States. Harvard: University Press. 
Holden, P. (2011). A New Beginning? Does the Union for the Mediterranean Herald a New Functionalist Approach to Co-operation in the Region? Mediterranean Politics, 16(1):155-169. Huysmans, J. \& Squire, V. (2009). Migration and Security. In: Dunn Cavelty, M. \& Mauer, V. (eds.) Handbook of Security Studies. London: Routledge, 169-179.

Kasparek, B. \& Wagner, F. (2012). Local Border Regimes or a Homogeneous External Border? The Case of the European Union's Border Agency Frontex. In: Geiger, M. \& Pécoud, A. (eds.) The New Politics ofInternational Mobility. Migration Management and its Discontents. Osnabrück: Institut für Migrationsforschung und Interkulturelle Studien, 173-19o.

Kaunert, C. \& Léonard, S. (2012). The European Union Asylum Policy After the Lisbon Treaty and the Stockholm Programme: Towards Supranational Governance in a Common Area of Protection? Refugee Survey Quarterly, 31(4): 1-20.

Kausch, K. \& Youngs, R. (2009). The End of the Euro-Mediterranean Vision. International Affairs, 85(5): 963-975.

Kienle, E. (2012). Egypt Without Mubarak, Tunisia After Bin Ali: Theory, History and the 'Arab Spring'. Economy and Society, 41(4): 532-557.

Lavallée, C. (2011). The International Role of the EU After the Lisbon Treaty: Between Internal Reforms and External Challenges. The Brown Journal of World Affairs. Available at http:// www.bjwa.org/article.php?id=No8E4mdtxQUYKe37z7bJZJbQGBNNSWm99Geryoo6 (accessed 6 August 2013).

Longo, F. (2013). Justice and Home Affairs as a New Dimension of the European Security Concept. European Foreign Affairs Review, 18(1): 29-46.

Maroukis, T. \& Triandafyllidou, A. (2013). Mobility Partnerships: A Convincing Tool for the EU's Global Approach to Migration? Notre Europe Policy Paper 76, Brussels: Jacques Delors Institute. Available at http://www.notre-europe.eu/media/mobilityparnershipsmaroukistriandafyllidou-ne-jdi-febi3.pdf (accessed 14 April 2013).

Martin, M. (2012). Extension of Mobility Partnerships With Euro-Mediterranean Partners. Panorama, 279-283. Available at http://www.statewatch.org/news/2013/jan/mp-article. pdf (accessed 14 April 2013).

Mink, J. (2012). EU Asylum Law and Human Rights Protection: Revisiting the Principle of NonRefoulement and the Prohibition of Torture and Other Forms of Ill-Treatment. European Journal of Migration and Law, 14(2): 119-149.

Monar, J. (2004) The EU as an International Actor in the Domain of Justice and Home Affairs. European Foreign Affairs Review, 9(3): 395-415.

Mourad, H. (2008). Nous Voulons Accueillir d'Avantage d'Étudiants Égyptiens. Al-Ahram Hebdo, 712, 30 April - 4 May. Available at http://hebdo.ahram.org.eg/arab/ahram/20o8/4/30/invio. htm (accessed 3 August 2013, cache).

Nassar, H. (2008). Temporary and Circular Migration: The Egyptian Case. CARIM Analytical and Synthetic Notes 9. San Domenico di Fiesole: Euro-Mediterranean Consortium for Applied Research on International Migration. Available at http://cadmus.eui.eu/bitstream/ handle/1814/8330/CARIM_AS\%26N_2008_o9.pdf?sequence=1 (accessed 7 August 2013)

Noi, A.U. (2012). The Arab Spring: Should Turkey Coordinate Its Foreign Policy With the European Union? Mediterranean Quarterly, 23(3): 63-81.

OECD (2013) International Migration Outlook 2013. Paris: Organisation for Economic Cooperation and Development.

Panizzon, M. (2012). Readmission Agreements of the EU Member States: A Case for EU Subsidiarity or Dualism? Refugee Survey Quarterly, 31(4): 101-133.

Pawlak, P. (2012). The Unintentional Development of the EU's Security Governance Beyond Borders. European Foreign Affairs Review, 17(2 Special Issue): 87-107. 
Reiterer, M. (2009). From the (French) Mediterranean Union to the (European) Barcelona Process: The 'Union for the Mediterranean' as Part of the European Neighbourhood Policy. European Foreign Affairs Review, 14(3): 313-336.

Reslow, N. (2012). The Role of Third Countries in EU Migration Policy: The Mobility Partnerships. European Journal of Migration and Law, 14(4): 393-415.

Rettman, A. (2012). Netherlands Defends Border Control Project. EUObserver. 3 January. Available at http://euobserver.com/justice/114751 (accessed 6 August 2013).

Reynaert, V. (2011). Preoccupied With the Market: The EU as a Promoter of 'Shallow' Democracy in the Mediterranean. European Foreign Affairs Review, 16(5): 623-637.

Roig, A. \& Huddleston, T. (2007). EC Readmission Agreements: A Re-evaluation of the Political Impasse. European Journal of Migration and Law, 9: 363-387.

Rosenblum, M.R.(2010). Immigrant Legalization in the United States and European Union:Policy Goals and Program Design. MPI Policy Brief. Available at http://www.migrationpolicy.org/ research/immigrant-legalization-united-states-and-european-union (accessed 7 April 2014).

Schlumberger, O. (2011). The Ties That Do not Bind: The Union for the Mediterranean and the Future of Euro-Arab Relations. Mediterranean Politics, 16(1): 135-153.

Seeberg, P. (2012). The Arab Revolts and the Strategic Relations Between the EU and the MENA Region - the Case of Egypt. Odense: University of Southern Denmark. Available at http:// static.sdu.dk/mediafiles/D/8/8/\% ${ }_{7} \mathrm{BD} 884570 \mathrm{oF}-98 \mathrm{~A} 5-4203-953 \mathrm{~B}-\mathrm{B} 450 \mathrm{~A}_{3} \mathrm{~B} 0{ }_{2} \mathrm{E}_{7} \%{ }_{7}$ Dog12PS. pdf (accessed 16 April 2013).

Seiffart, O. (2012). The Development of the European Border Surveillance System (EUROSUR). In: Burgess, P. \& Gutwirth, S. (eds.) A Threat Against Europe? Security, Migration, and Integration. Brussels: VUB Press, 133-152.

Spijkerboer, T. (2007). The Human Costs of Border Control. European Journal of Migration and Law, 9(1): 127-139.

Teti, A. (2012). The EU's First Response to the 'Arab Spring': A Critical Discourse Analysis of the Partnership for Democracy and Shared Prosperity. Mediterranean Politics, 17(3): 266-284.

Thielemann, E. (2012). How Effective are National and EU Policies in the Area of Forced Migration? Refugee Survey Quarterly, 31(4): 21-37.

Today's Zaman (2013). Ankara not to Implement Readmission Deal if Visa Deal not Granted by $E U$. 10 July. Available at http://www.todayszaman.com/newsDetail_getNewsById.action;js essionid=27602FE8E161BE31C9629E50055761E9? newsId=320517\&columnistId $=0$ (accessed 3 Aug. 2013).

Trauner, F. \& Carrapico, H. (2012). The External Dimension of EU Justice and Home Affairs After the Lisbon Treaty: Analysing the Dynamics of Expansion and Diversification. European Foreign Affairs Review, 17 (2 Special Issue): 1-18.

Triandafyllidou, A. \& Ambrosini, M. (2011). Irregular Immigration Control in Italy and Greece: Strong Fencing and Weak Gate-keeping Serving the Labour Market. European Journal of Migration and Law, 13(3): 251-273.

Völkel, J.C. (2008). Die Vereinten Nationen im Spiegel Führender Arabischer Tageszeitungen. Wiesbaden: VS Verlag.

Völkel, J.C. (2013). Red Card for Morsi, Yellow Card for Democracy. OpenDemocracy, 3 July. Available at http://www.opendemocracy.net/jan-v\%C3\%B6lkel/red-card-for-morsi-yellowcard-for-democracy (accessed 7 April 2014).

Völkel, J.C. (2014). More for More, Less for Less - More or Less: A Critique of the EU's Arab Spring Response à la Cinderella. European Foreign Affairs Review, 19(2): 263-282.

Vollmer, B. (2011). Policy Discourses on Irregular Migration in the EU - 'Number Games' and 'Political Games'. European Journal of Migration and Law, 13(3): 317-339. 


\begin{abstract}
About the author
Jan Claudius Völkel is DAAD visiting professor at the Euro-Mediterranean Studies Programme, Faculty of Economics and Political Science, Cairo University. Prior to this, he held teaching and research assignments with the universities of Freiburg, Salzburg, Innsbruck, Duhok (Iraqi Kurdistan) and the European University Institute, and was a visiting researcher at the Université de Montréal. He is regional coordinator for the Middle East and North Africa region at the Bertelsmann Transformation Index (www.bti-project.org).

Email:jan.voelkel@daadcairo.org
\end{abstract}

\title{
c) $(9) \Theta$
}

